\title{
Microbiological, physico-chemical and management para- meters impinging on the efficiency of small water treatment plants in the Limpopo and Mpumalanga Provinces of South Africa
}

\author{
CL Obi ${ }^{1 *}$, MNB Momba², A Samie ${ }^{4}$, JO Igumbor ${ }^{3}$, E Green $^{4}$ and E Musie ${ }^{4}$ \\ ${ }^{1}$ College of Agriculture and Environmental Sciences, School of Agriculture and Life Sciences, University of South Africa, \\ Skinner Street, Sunnyside, PO Box 392, Pretoria, South Africa \\ ${ }^{2}$ Department of Water Care, Tshwane University of Technology, Arcadia Campus, Pretoria, South Africa \\ ${ }^{3}$ Department of Public Health, University of Venda, Thohoyandou, South Africa \\ ${ }^{4}$ Department of Microbiology, University of Venda, Thohoyandou, South Africa
}

\begin{abstract}
In the wake of the growing dependence on small water treatment plants (SWTPs) in providing quality water to rural areas and the global burden of water borne diseases, this study sought to examine the efficiency of 55 SWTPs located in rural or peri-urban areas of Limpopo and Mpumalanga Provinces in order to gauge the safety of water supply for human consumption. The microbiological and physical parameters of raw water, treated water and water in the distribution systems were examined using standard methods. Management issues impacting on quality of water supply were determined by use of questionnaires and focus group discussions. Results obtained showed that the $\mathrm{pH}$, turbidity, temperature and conductivity of the raw water in SWTPs studied in both provinces ranged between 6.46 to $9.05 \mathrm{pH}$ units, 0.19 to $8.0 \mathrm{NTU}, 15.4^{\circ} \mathrm{C}$ to $31.40^{\circ} \mathrm{C}$ and 44.40 .4 $\mu \mathrm{S}$ to $108 \mu \mathrm{S}$ respectively. Water quality compliance at point of use (treated water) according to the Department of Water Affairs and Forestry of South Africa guidelines in SWTPs studied in both provinces were $85 \%$ for faecal coliforms and $69 \%$ for total coliforms. In the distribution systems, TCCs, FCCs and HPCs were within recommended limits except for few SWTPs suggesting a possibility of inadequate treatment and this may represent post-treatment contamination and possible risk of infection from these water supply sources. Physical parameters were generally within the recommended ranges . In terms of administrative issues, some plant operators did not have adequate knowledge of the functioning of the SWTPs and most were unable to calculate chlorine dosage, determine flow rates or undertake repairs of basic equipment. Poor working conditions, frequent stock depletion of chemicals, lack of maintenance culture , lack of emergency preparedness and poor communication were also cited .

The study has revealed that the microbiological quality of raw water was very poor but that water treatment was efficient in the majority of SWTPs studied in both provinces. Regular monitoring of microbial and physico-chemical parameters of water quality served by the different SWTPs to the population is recommended to gauge their safety for human consumption. Issues such as enhanced incentives and periodic training of plant operators, improved communication and conditions of service , periodic stock inventory and entrenchment of maintenance culture may be necessary to ensure sustained and efficient water distribution systems.
\end{abstract}

Keywords: water treatment plants, water quality, Limpopo, Mpumalanga, RSA provinces and management

\section{Introduction}

In South Africa, water infrastructure is well developed in urban areas and the majority of the urban population utilise potable water. In rural communities, water infrastructure is either poorly developed or non-existent. In rural areas, the majority of the populace rely on raw water sources such as rivers and ponds which are faecally contaminated and usually not treated. River water sources were found to be of poor microbiological quality and unsafe for human consumption (Obi et al., 2002; Momba et al., 2000; Muyima and Ngcakani, 1998). Contaminated water sources are vehicles for the transmission of water-borne diseases such as cholera, shigellosis and Campylobacteriosis (Ashbolt, 2004).

Around the $19^{\text {th }}$ century, outbreaks of diseases like cholera emphasised the necessity of disinfecting drinking water. The World Health Organisation (WHO) estimated that about $1.1 \mathrm{bn}$.

\footnotetext{
* To whom all correspondence should be addressed.

욜 +27 12 352-4032; fax: 2712 352-4117;

e-mail: obicl@unisa.ac.za

Received 16 May 2006; accepted in revised form 17 February 2007.
}

people globally drink unsafe water (WHO, 2000) and the vast majority of diarrhoeal diseases in the world (88\%) are attributable to unsafe water, sanitation and hygiene. Approximately $3.1 \%$ of annual deaths $(1.7 \mathrm{~m}$.) and $3.7 \%$ of the annual health burden (disability adjusted life years [DALYs]) world-wide $(54.2 \mathrm{~m}$.) are attributed to unsafe water, sanitation and hygiene (WHO, 2003).

In order to prevent water-borne diseases water is treated to eliminate pathogens. In rural and peri-urban areas, water sources are usually treated in units called small water treatment plants (SWTPs). Small water treatment plants are defined as water treatment systems that are installed in areas, which are not well serviced, and which do not normally fall within the confines of urban areas. SWTPs include water supplies from boreholes and springs that are chlorinated, small treatment systems for rural communities, treatment plants of small municipalities and treatment plants for establishments such as rural hospitals, schools, clinics and forestry stations. Most of these applications fall within the category of small plants of less than $2.5 \mathrm{M \ell} / \mathrm{d}$, although plants of up to $25 \mathrm{M \ell} / \mathrm{d}$ may sometimes also fall into this category (DWAF, 1998). 


\section{Location of Water treatment plants visited}

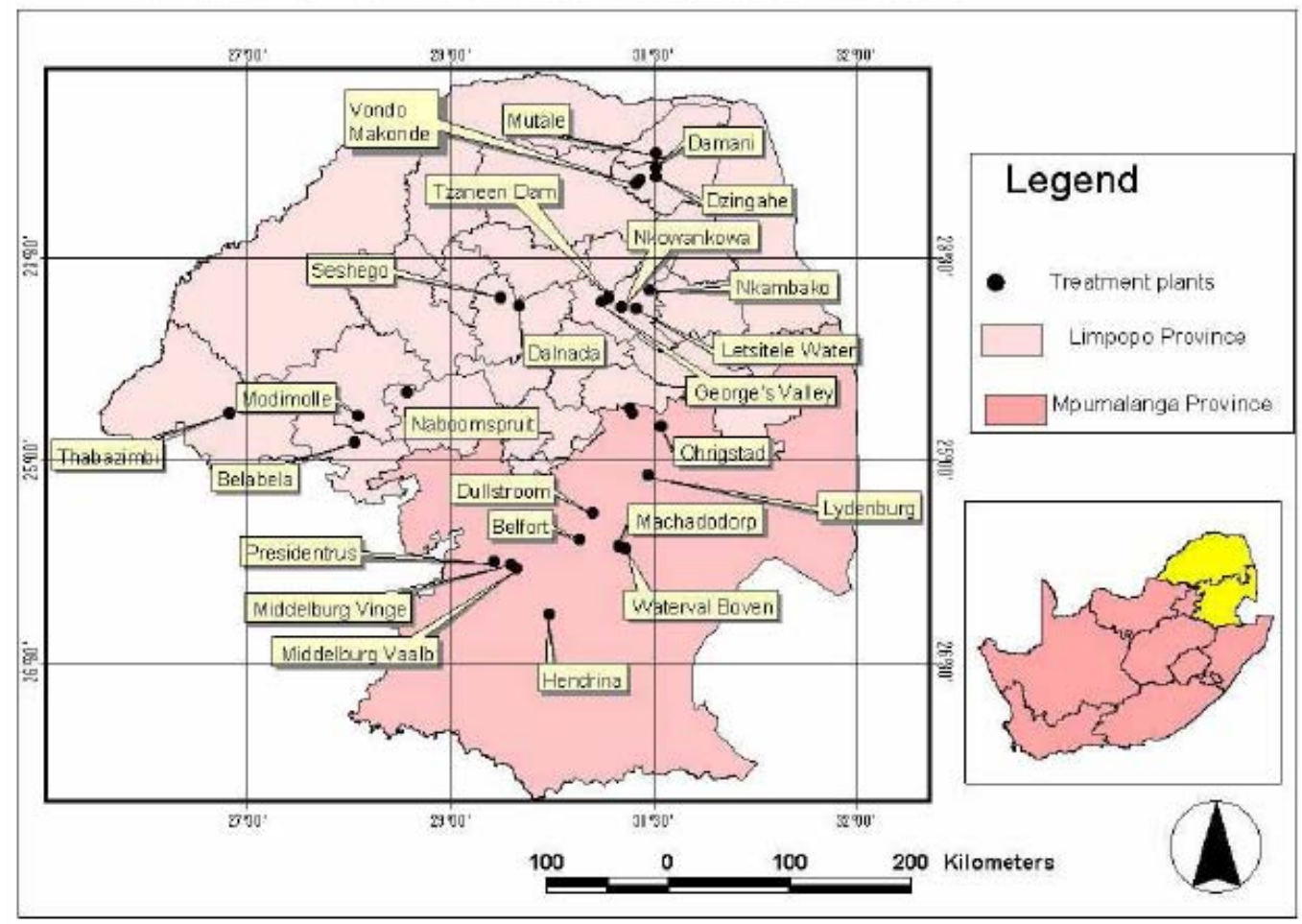

Figure 1

Location of SWTPS studied

During the last century, drinking water treatment has been improved with the standardisation of process treatment. This process generally includes pre-disinfection of water supplied directly from the river, coagulation-flocculation, sedimentation, and post-disinfection (DOH, 2003). A small amount of chlorine is added or some other disinfection method is used to kill bacteria or micro-organisms that may be in the water. Filtration and disinfection are the critical points of the treatment process (Edberg et al., 2000). Different filtration systems can be used and the most common material used is sand in slow sand filtration, rapid gravity sand filtration or in some cases press filters. Disinfection is commonly done by chlorination (in different forms), ozonation and ionisation (Zhang et al., 2004).

The characteristics of drinking water may be determined by different properties such as the presence or absence of bacterial indicators, ions, conductivity, $\mathrm{pH}$, turbidity and temperature. The conductivity of water is related to the concentration of ions capable of carrying an electrical current. High water conductivity indicates high ion content and might have consequences like pipes bursting or other effects on the skin and the use of soap The conductivity of water is also related to the total dissolved solids in the water (Anon, 1994). Turbidity may affect the efficiency of the disinfection process (Caslake et al, 2004).

The capacity of any SWTP to provide acceptable water quality depends on the performance of each functional unit in the plant including flocculation-sedimentation, filtration and disinfection. Management and administration of SWTPs determine the quality of the final water. Generally, people working at SWTPs are called operators. Their main role in the plant is to control the equipment and processes that remove or destroy harmful materials, chemical compounds and micro-organisms from the water. Their knowledge is thus important for the provision of water of good quality.
In this study, the efficiency and capability of SWTPs located in rural or peri-urban areas of the Limpopo and Mpumalanga Provinces in providing safe water were assessed by examining microbiological and physical parameters of raw water, treated water and water in distribution systems using standard methods. Information on the design capacity of SWTPs, actual capacity as well as administrative issues was also assessed.

\section{Materials and methods}

\section{Study site}

The study sites were rural and peri-urban communities in Limpopo Province (Phiphidi, Vondo, Mutale, Dzingahe, Mudaswali, Damni, Dzindi, Mutshedzi, Tshedza, Tshifhire, Tshakhuma regional, Tshakhuma, Makhado, Messina, Shikudu, Mhinga, Malamulele, Nkowankowa, Semerela, Thapane, Nkambako, Letsitele, Tzaneen, George's Valley) and the Mpumalanga Province (Lydenberg, Hazyview, White river RE, White river country estate, Malelane, KaNyamazane regional, KaNyamazane, Nelspruit, Matsulu, Sabie, Machadodorf, Kruger Dan-4 Hendrina, Watervaal, Belfast, Witbank, Presidentsus, Middelburg, Dullstroom) of South Africa. Limpopo and Mpumalanga Provinces are situated in the far north and north- east of South Africa respectively and they rank as the least resourced provinces.

\section{Plant survey}

A survey of technical and administrative issues of various water treatment plants was conducted. The survey started with a short introductory meeting followed by a plant tour and interview with the plant operators and other superintendents, councillors or representatives. The plant tour was done in the presence of 
the superintendent of the plant or his representative and at least one plant operator. Different units comprising the plants were inspected in detail to monitor their functions on the day of the survey. Information concerning administrative issues such as the training of operators, their salaries, benefits, decision making, ownership of the SWTPs, security and any upgrade of the plant was sought through the use of questionnaires. Measurements were made to determine the size of the baffling chambers, sedimentation tanks and filters. Type of coagulant, filtration types, disinfection types, lime dosage as well as dosing pumps were determined during the plant tour. The operators present at the plant at the time of survey were interviewed individually.

\section{Sample collection}

A total of 55 rural and peri-urban SWTPs and distribution systems from the two provinces were visited during the period 26 August to 10 March 2005. Water samples were collected from raw water, final water and water at point of use, and three samples were collected from each plant.

\section{Physico-chemical analysis}

Physico-chemical analyses were conducted on site. Values measured included turbidity, temperature, conductivity and $\mathrm{pH}$ of water. The JENWAY $\mathrm{pH}$ meter 3150 was used for the measurement of the $\mathrm{pH}$; The CRISON CM35 Conductivity meter was used for the measurement of conductivity whilst the $\mathrm{HACH}$ Model 2100P portable turbidimeter was used to measure the turbidity of the samples. All the measurements were done in triplicate and the geometric means were considered.

\section{Microbiological analysis}

The samples collected were transported on ice to the Microbiology Laboratory, University of Venda for microbiological assays. Microbiological parameters such as HTPs, TCCs and faecal coliforms were determined using standard methods (WHO, 2001). The spread plate method was used for all counts. Plate count agar, m-ENDO agar and m-FC agar were used for heterotrophic counts, total coliform and faecal coliform counts respectively. Each test was done in triplicate and the geometric means were recorded. Attempts were made to isolate individual microorganisms including E. coli, Salmonella spp., Shigella spp.,
Campylobacler spp., Vibrios, Enterococus and Aeromonas using standard methods as previously described (Obi et al., 2004) Briefly, a sample of the water was inoculated on specific media (EMB for E. coli, SS agar for Salmonella and Shigella, Skirrow's media for Campylobacter, TCBS for Vibrio, Enterococcus selective agar for Enterococcus). The different organisms were further identified by biochemical tests such as Gram staining, oxidase, catalase, urea hydrolysis, motility, hydrogen sulphide production and gelatine hydrolysis (Obi et al., 2004).

\section{Results and discussion}

\section{Ownership}

Three categories of ownership of the SWTPs namely local municipalities, Department of Water Affairs and Forestry (DWAF) and private ownership were identified in both provinces (Table 1). Local municipalities were the major owners in Mpumalanga with $17 / 19(89 \%)$ of the SWTP plants studied whereas in Limpopo Province, plant ownership was divided between local municipalities 15/36 (42\%) and DWAF 20/36 (56\%). One (2.8\%) plant was co- owned by DWAF and Biowaters in Limpopo. In Mpumalanga, two (11\%) SWTPs (Nelspruit and Matsulu) were owned by Biowaters, which is a private company that also coowns one plant in Limpopo together with DWAF. Some of the plants were noted to be in a transitional period, ownership being transferred from DWAF to the municipalities. The performance of treatment plants in the private company was beyond the scope of this study and was not assessed.

\section{Capacity}

The SWTPs were classified into four categories according to their actual capacities. In total $10(18 \%)$ of the plants in Limpopo and Mpumalanga Provinces had an actual capacity of less than $1 \mathrm{M \ell} / \mathrm{d}$ (Category 1), 38 (69\%) had an actual capacity of between 1 and $25 \mathrm{M} \ell / \mathrm{d}$ (Category 2), 4 (7\%) had an actual capacity of between 25 and $\sim 50 \mathrm{M} \ell / \mathrm{d}$ (Category 3 ) and $3(5 \%)$ had an actual capacity of more than $50 \mathrm{M \ell} / \mathrm{d}$ (Category 4) in both Provinces (Table 1). Most of the plants in both Limpopo $(69 \%)$ and Mpumalanga (68\%) could be classified as a Category two (Table 1).

In Mpumalanga only one treatment plant (5\%) was recorded in Category 1. The largest plant visited was in Witbank with

\begin{tabular}{|c|c|c|c|c|c|c|c|c|}
\hline Classification of & studied w & ater treatmen & $\begin{array}{r}\text { TAE } \\
\text { t plants in } \\
\text { water }\end{array}$ & $\begin{array}{l}\text { LE } 1 \\
\text { impopo a } \\
\text { ources }\end{array}$ & d Mpum & alanga acco & ng to $\mathrm{ca}$ & pacity and \\
\hline Province & Category & Capacity & Number of & Water S & ources & & wner Typ & \\
\hline & & $\begin{array}{c}\text { Current flow: } \\
\text { MLD }\end{array}$ & plants & $\begin{array}{l}\text { Surface } \\
\text { Water }\end{array}$ & $\begin{array}{l}\text { Ground } \\
\text { Water }\end{array}$ & Municipality & DWAF & $\begin{array}{c}\text { Private } \\
\text { (Biowaters) }\end{array}$ \\
\hline Limpopo (5 districts & One & $\leq 1$ & $9(25 \%)$ & $7(19 \%)$ & $2(6 \%)$ & $3(8 \%)$ & $6(17 \%)$ & 0 \\
\hline \& 12 local munici- & Two & $1.1-25$ & $25(69 \%)$ & $24(67 \%)$ & $1(3 \%)$ & $12(33 \%)$ & $12(33 \%)$ & $1(3 \%)$ \\
\hline palities & Three & $25.1-50$ & $2(6 \%)$ & $2(6 \%)$ & 0 & 0 & $2(6 \%)$ & 0 \\
\hline & Four & $>50$ & 0 & 0 & 0 & 0 & 0 & 0 \\
\hline Total & & & 36 & $33(92 \%)$ & $3(16 \%)$ & $15(42 \%)$ & $20(56 \%)$ & $(3 \%)$ \\
\hline Mpumalanga & One & $\leq 1$ & $1(5 \%)$ & $1(5 \%)$ & 0 & $1(5 \%)$ & 0 & 0 \\
\hline (2 districts and 6 & Two & $1.1-25$ & $13(68 \%)$ & $2(63 \%)$ & $1(5 \%)$ & $12(63 \%)$ & 0 & $1(5 \%)$ \\
\hline local minucipalities & Three & $25.1-50$ & $2(11 \%)$ & $2(11 \%)$ & 0 & $2(11 \%)$ & 0 & 0 \\
\hline & Four & $>50$ & $3(16 \%)$ & $3(16 \%)$ & 0 & $2(11 \%)$ & 0 & $1(5 \%)$ \\
\hline Total & & & 19 & $18(95 \%)$ & $1(5 \%)$ & $17(89 \%)$ & 0 & $2(11 \%)$ \\
\hline
\end{tabular}


a capacity of about $120 \mathrm{M} \ell / \mathrm{d}$. Two (11\%) of treatment plants were listed under Category 3 while $3(16 \%)$ plants were in Category 4.

In Limpopo $9(25 \%)$ and $2(6 \%)$ of the SWTPs studied were classified into Categories 1 and 2 respectively. The largest plant in Limpopo Province was found in Mhinga with a design capacity of $37 \mathrm{M} \ell / \mathrm{d}$. Unlike in Mpumalanga, some plants, particularly those in Waterberg, Sekhukhune and Capricorn Districts obtained a supplementary amount of treated water from other companies situated in the Gauteng area because the functioning period of some of the plants was limited to 2 or $3 \mathrm{~d}$ per week. This actually decreased the availability of treated water and in turn made the local population to rely on untreated water from rivers.

\section{Technical issues}

Drinking water sources: Surface water from rivers and dams was noted to be the main source of water treated by the different SWTPs in Limpopo and Mpumalanga. It was noted that $92 \%$ and $95 \%$ of SWTPs employed the use of surface water in the Limpopo and Mpumalanga Provinces respectively, whereas less than $9 \%$ made use of groundwater (boreholes or open wells) in both provinces.

Treatment processes: Table 2 indicates the different treatment methods used by the SWTPs in the Limpopo and Mpumalanga Provinces. Virtually all the SWTPs (92\%) in Limpopo and (95\%) in Mpumalanga employed conventional water treatment processes such as coagulation, flocculation, sedimentation, filtration and chlorination. The most common filtration system in SWTPs in both provinces was rapid gravity and sand filtration, constituting $61 \%$ and $79 \%$ of SWTPs in Limpopo and Mpumalanga respectively, followed by pressure filters. Only $11 \%$ and
$5 \%$ of the SWTPs in Limpopo and Mpumalanga respectively, used slow sand filtration (Table 2).

In Mpumalanga, lime was used in $95 \%$ of the plants to stabilise the pH. In Limpopo, lime was used in 56\% of SWTPs, whereas soda ash was used in $17 \%$ of plants (Table 2).

During the survey period, solid and liquid coagulants were used by the plants. Liquid coagulants of the polymeric coagulant type such as sud floc, ferri floc, ultrafloc, Polyelectrolyte U3800 and alu floc were used in 64\% of the SWTPs investigated whilst solid coagulants, mainly aluminium chloride and aluminium phosphate, were used in $22 \%$ of the plants. In Mpumalanga, liquid coagulants were used in $84 \%$ of the plants while solid coagulants were used in only $16 \%$ of the SWTPs investigated. Some plants used both types of coagulants depending on the availability. Alum and lime were generally dosed manually using a mechanical drier feeder. The polyelectrolytes were generally dosed using different kinds of pumps including ALLDOS, MILTON ROY, PROMINENT, and Elatrin dosing systems. The coagulant dosage was generally determined by experience, depending, particularly, on the appearance of water. Although some of the plants had the necessary equipment, such as the jar test apparatus, none was conducting the test to determine the necessary amount of chemicals to be used.

Pipe flocculation was common in $15 \%$ of the plants (with only one in Mpumalanga) while 80\% used open channel flocculation. Pipe flocculation generally was used in packaged plants with limited space. Sedimentation tanks were circular or horizontal and the flow pattern of water into the tanks was generally down flow. The different filtration systems used by the plants are shown in Table 2. The data for the pressure filters and slow sand filters are also presented (Table 2). Some of the plants visited were at a stage of upgrading or planning to upgrade. The type of upgrade generally suggested included the construction of new filters and sedimentation systems.

\begin{tabular}{|c|c|c|c|c|c|c|c|c|c|c|c|c|c|c|c|}
\hline & & & Treatn & nent $n$ & lethod & $s$ in SV & $\begin{array}{l}\text { TABL } \\
\text { NTP's }\end{array}$ & $\begin{array}{l}\text { E } 2 \\
\text { in Lim }\end{array}$ & popo a & and Mpu & Imalan & & & & \\
\hline Province & \begin{tabular}{|l|} 
Cate- \\
gory
\end{tabular} & $\begin{array}{l}\text { Conve } \\
\text { al trea }\end{array}$ & $\begin{array}{l}\text { ntion- } \\
\text { tment }\end{array}$ & Filtr & ation sy & stem & $\begin{array}{r}\mathrm{P} \\
\text { stabili }\end{array}$ & $\begin{array}{l}\mathrm{H} \\
\text { sation }\end{array}$ & $\begin{array}{l}\text { Typ } \\
\text { coag }\end{array}$ & $\begin{array}{l}\text { pe of } \\
\text { gulant }\end{array}$ & Disinf & ection & & $\begin{array}{l}\text { borator } \\
\text { quipmen }\end{array}$ & \\
\hline & & Yes & DIS & SSF & RGSF & $\mathrm{PF}$ & Lime & $\begin{array}{c}\begin{array}{c}\text { Soda } \\
\text { ash }\end{array} \\
\end{array}$ & Solid ${ }^{a}$ & $\begin{array}{c}\text { Liquid }^{b} \\
\text { (Poly) }\end{array}$ & $\begin{array}{l}\mathrm{Cl}_{2} \\
\text { gas }\end{array}$ & HTH & Basic $^{c}$ & $\begin{array}{c}\text { Well } \\
\text { equip- } \\
\text { ped d }^{\text {d }}\end{array}$ & No \\
\hline Limpopo & One & 7 & 1 & 1 & 2 & 4 & 3 & 3 & 3 & 4 & 3 & 8 & 0 & 0 & 9 \\
\hline & Two & 24 & 1 & 3 & 19 & 3 & 16 & 2 & 5 & 17 & 21 & 15 & 3 & 1 & 21 \\
\hline & Three & 2 & 0 & 0 & 1 & 1 & 1 & 1 & 0 & 2 & 2 & 2 & 2 & 0 & 0 \\
\hline & Four & 0 & 0 & 0 & 0 & 0 & 0 & 0 & 0 & 0 & 0 & 0 & 0 & 0 & 0 \\
\hline Total & & $\begin{array}{c}33 \\
(92 \%)\end{array}$ & \begin{tabular}{|c|}
2 \\
$(6 \%)$
\end{tabular} & \begin{tabular}{|c|}
4 \\
$(11 \%)$
\end{tabular} & $\begin{array}{c}22 \\
(61 \%)\end{array}$ & $\begin{array}{c}8 \\
(22 \%)\end{array}$ & $\begin{array}{c}20 \\
(56 \%)\end{array}$ & $\begin{array}{c}6 \\
(17 \%)\end{array}$ & $\begin{array}{c}8 \\
(22 \%)\end{array}$ & $\begin{array}{c}23 \\
(64 \%)\end{array}$ & $\begin{array}{c}26 \\
(72 \%)\end{array}$ & \begin{tabular}{|c|}
25 \\
$(69 \%)$
\end{tabular} & $\begin{array}{c}5 \\
(14 \%)\end{array}$ & $\begin{array}{c}1 \\
(3 \%)\end{array}$ & $\begin{array}{c}30 \\
(83 \%)\end{array}$ \\
\hline
\end{tabular}

\begin{tabular}{|l|c|c|c|c|c|c|c|c|c|c|c|c|c|c|c|}
\hline Mpumalanga & One & 1 & 0 & 0 & 0 & 1 & 1 & 0 & 0 & 1 & 0 & 1 & 1 & 0 & 1 \\
\hline & Two & 12 & 1 & 1 & 10 & 3 & 12 & 1 & 2 & 10 & 11 & 2 & 4 & 0 & 9 \\
\hline & Three & 2 & 0 & 0 & 2 & 0 & 2 & 0 & 0 & 2 & 2 & 0 & 1 & 1 & 0 \\
\hline & Four & 3 & 0 & 0 & 3 & 1 & 3 & 0 & 0 & 3 & 3 & 0 & 2 & 0 & 1 \\
\hline Total & & 18 & 1 & 1 & 15 & 5 & 18 & 1 & 2 & 16 & 16 & 3 & 3 & 1 & 11 \\
& & $(95 \%)$ & $(5 \%)$ & $(5 \%)$ & $(79 \%)$ & $(26 \%)$ & $(95 \%)$ & $(5 \%)$ & $(11 \%)$ & $(84 \%)$ & $(84 \%)$ & $(16 \%)$ & $(42 \%)$ & $(5 \%)$ & $(56 \%)$ \\
\hline
\end{tabular}

Conventional treatment $=$ Process involving coagulation, flocculation, sedimentation, filteration and chlorination

DIS $=$ Disinfection only

No $=$ No treatment

$S S F=$ Slow Sand Filters, $R G S F=$ Rapid Gravity Sand filters, $P F=$ Pressure filters

$a=$ Aluminium sulphate or aluminium chloride

$b=$ polymeric coagulant such as sud floc, polyelectrolyte $u 3800$, alu floc

$c=$ colorimeter and turbidity meter

$d=$ basic + jar test, $\mathrm{pH}$ meter and microbiology 
In terms of the disinfectants, most of the plants used chlorine gas for disinfection with granular chlorine (HTH) as backup. The dosage was generally not calculated but determined arbitrarily by experience and most supervisors and operators did not have knowledge of the recommended value of residual chlorine. Generally, smaller plants of less than $1 \mathrm{M} / \mathrm{d}$ used HTH exclusively for disinfection. Pretreatment was rare and was observed in only one plant (White River). No plant was observed to use sodium hypochlorite (liquid chlorine) for disinfection. In brief, chlorine was used as the only disinfectant in $72 \%$ and $84 \%$ of the SWTPs studied in Limpopo and Mpumalanga Provinces respectively. HTH was used in $69 \%$ and $16 \%$ of SWTPs studied in Limpopo and Mpumalanga respectively (Table 2). Virtually all the plants in both provinces were poorly equipped in terms of laboratory facilities. Waste management was not taken seriously and most plants generally discharged the backwash water and the sludge from the clarifier and sedimentation tanks into the environment.

\section{Physico-chemical water quality}

Turbidity: The mean water turbidity figures from the two provinces exceeded international limits for no risks (0-1 NTU). This concern was however more pronounced in Mpumalanga Province where the mean turbidity of water at point of use was about three times the higher limit for no risk and a had much wider standard deviation when compared to the figures from Limpopo Province (Tables 3 and 4). The observed water turbidity figures at point use in Mpumalanga, however, ranged from as little as 0.17 NTU to 4.30 NTU and with an average of 2.71 (SD =3.4). Similarly the turbidity of water at point of use in Limpopo Province ranged from 0.26 NTU to 6.0 NTU and with a mean of $1.72(\mathrm{SD}=2.0)$.

The excessive turbidity in water can cause problems with water purification processes such as flocculation and filtration, which may increase treatment cost (DWAF, 1998). The turbidity might also have a negative impact on the efficiency of disinfec- tion by limiting the bactericidal/ disinfectant effect of chlorine. The South African Target Water Quality Range (DWAF, 1996a) for turbidity in water for domestic water supply is 0 to 1 NTU.

When highly turbid waters are chlorinated there is a tendency for an increase in trihalomethane (THM) precursor formation (Nissinen et al, 2002). Waters with elevated turbidity are often associated with the possibility of microbiological contamination, as high turbidity makes it difficult to disinfect water properly (DWAF, 1998). Soil erosion and runoff form the catchments could be the source of high turbidity in the water systems. Turbidity has been reported to hide disease causing microorganisms. This could have devastating consequences on human health.

The filtration unit was the limiting factor during the survey period. The units in most of the plants were either defective or overloaded. Most plants used rapid gravity sand filters. This method is quite effective when used by an experienced operator. In one of the plants whose final effluent was contaminated, there were 14 rapid gravity sand filters. However, at the time of the survey, four of them were under repair but they were still being used by the plant operator. This resulted in high turbidity of the water and the contamination of the final effluent by microorganisms.

Conductivity: The mean conductivity of water at point of use in Limpopo was higher than the recommended limit for no risk $(<70 \mathrm{~ms} / \mathrm{m})$. The conductivity figures for water at point of use in Limpopo province ranged from 33.51 to $98.0 \mathrm{~ms} / \mathrm{m}$, and with a mean of about $78 \mathrm{~ms} / \mathrm{m}$ (Table 6 ). Lesser conductivity figures of water at point of use were noted in Mpumalanga ranging from 35.60 to $93.20 \mathrm{~ms} / \mathrm{m}$ and with a mean of $72.00 \mathrm{~ms} / \mathrm{m}$ (SD = 24.73). There was also a noted increase in the mean conductivity of raw water and water at point of use in both provinces (Tables 3 and 4)

$\boldsymbol{p H}$ : The average $\mathrm{pH}$ of raw, final and water at point of use in both provinces water within international limits for no risk

TABLE 3

Physicochemical properties of raw water, final water and water at point of use from small water treatment plants in Mpumalanga Province

\begin{tabular}{|c|c|c|c|c|c|}
\hline Type & Number & Minimum & Maximum & Mean & Std. deviation \\
\hline Turbidity of raw water & 19 & 0.19 & 8.0 & 6.0 & 3.0 \\
\hline Turbidity of final water & 19 & 0.18 & 5.3 & 1.08 & 2.68 \\
\hline Turbidity of water at point of use & 19 & 0.17 & 4.30 & 2.71 & 3.4 \\
\hline Conductivity of raw water & 16 & 44.40 & 108.30 & 81.0 & 10.42 \\
\hline Conductivity of final water & 19 & 40.20 & 94.00 & 72.0 & 15.12 \\
\hline Conductivity of water at point of use & 19 & 35.60 & 93.20 & 72.0 & 24.73 \\
\hline pH of raw water & 19 & 6.90 & 9.05 & 7.96 & 0.52 \\
\hline $\mathrm{pH}$ of final water & 19 & 7.06 & 9.37 & 7.89 & 0.55 \\
\hline $\mathrm{pH}$ of water at point of use & 19 & 7.01 & 8.29 & 7.82 & $0 . .27$ \\
\hline Temperature of raw water & 19 & 15.40 & 26.30 & 21.61 & 3.08 \\
\hline Temperature of final water & 19 & 15.60 & 27.70 & 22.72 & 3.35 \\
\hline Temperature of water at point of use & 19 & 16.00 & 31.10 & 22.97 & 3.61 \\
\hline Chlorine dosage & 19 & 0.00 & 4.00 & 1.26 & 1.15 \\
\hline Current flow & 19 & 0.80 & 120.00 & 21.22 & 30.37 \\
\hline Residual chlorine final & 19 & 0.02 & 2.48 & 0.78 & 0.78 \\
\hline Residual chlorine at point of use & 19 & 0.04 & 0.59 & 0.24 & 0.186 \\
\hline
\end{tabular}




\begin{tabular}{|c|c|c|c|c|c|}
\hline \multicolumn{6}{|c|}{$\begin{array}{c}\text { TABLE } 4 \\
\text { Physicochemical properties of raw, final and water at point of use from small water treatment plants in Lim- } \\
\text { popo Province }\end{array}$} \\
\hline Type & Frequency & Minimum & Maximum & Mean & Std. deviation \\
\hline Turbidity of raw water & 34 & 0.30 & 6.8 & 4.0 & 2.8 \\
\hline Turbidity of final water & 35 & 0.25 & 4.00 & 2.00 & 1.32 \\
\hline Turbidity of water at point of use & 35 & 0.26 & 6.0 & 1.72 & 2.00 \\
\hline Conductivity of raw water & 35 & 55.48 & 105.00 & 87.00 & 11.00 \\
\hline Conductivity of final water & 35 & 36.21 & 108.50 & 85.00 & 13.26 \\
\hline Conductivity of water at point of use & 35 & 33.51 & 98.00 & 78.00 & 12.0 \\
\hline $\mathrm{pH}$ of raw water & 35 & 6.46 & 8.85 & 7.54 & 0.50 \\
\hline $\mathrm{pH}$ of final water & 35 & 6.50 & 9.64 & 7.78 & 0.86 \\
\hline $\mathrm{pH}$ of water at point of use & 35 & 6.66 & 9.23 & 7.71 & 0.72 \\
\hline Temperature of raw water & 35 & 18.20 & 31.40 & 24.62 & 3.86 \\
\hline Temperature of final water & 35 & 18.00 & 32.00 & 24.59 & 3.95 \\
\hline Temperature of water at point of use & 35 & 18.70 & 31.70 & 24.84 & 3.38 \\
\hline Chlorine dosage & 34 & 0.06 & 1.54 & 0.54 & 0.40 \\
\hline Current flow & 34 & 00.30 & 37.00 & 9.08 & 9.57 \\
\hline Residual chlorine final & 35 & 0.04 & 2.30 & 0.51 & 0.23 \\
\hline Residual chlorine at point of use & 35 & 0.02 & 1.01 & 0.25 & 0.22 \\
\hline
\end{tabular}

(6.0 to $9.0 \mathrm{pH}$ ) (Tables 3 and 4). The mean $\mathrm{pH}$ values for water at point of use in Mpumalanga province was $7.2 \mathrm{pH}$ units. The $\mathrm{pH}$ of water at point of use in Mpumalanga was similar to the figures from Limpopo where $\mathrm{pH}$ values ranged from 6.66 to $9.23 \mathrm{pH}$ and a mean of $7.71 \mathrm{pH}(\mathrm{SD}=0.73)$.

Temperature: In both provinces, the observed mean temperatures at point of use were, however, within acceptable limits of no risk $\left(15\right.$ to $\left.25^{\circ} \mathrm{C}\right)$ (Tables 3 and 4$)$.

Chlorine Residual: Residual chlorine at point of use was above acceptable limits of no risk in Limpopo Province. The mean residual chlorine at point of use was however within normal limits $(0.3$ to $0,6 \mathrm{mg} / \mathrm{m} \ell)$. The reading from Limpopo ranged from 0.04 to $2.30 \mathrm{mg} / \mathrm{m} \ell$ and with a mean of $0.51 \mathrm{mg} / \mathrm{m} *(\mathrm{SD}=0.23)$. The observations from Mpumalanga were similar with a range of chlorine residual at point of use of 0.04 to $0.59 \mathrm{mg} / \mathrm{m \ell}$ and a mean of $0.24 \mathrm{mg} / \mathrm{m} \ell(\mathrm{SD}=0.19)$

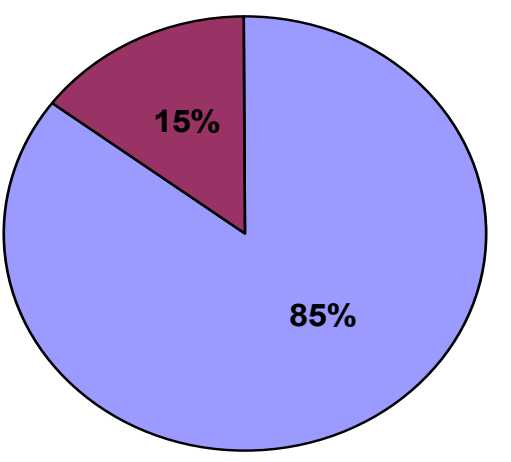

$\square$ Compliant

$\square$ Non - compliant

Figure 2

DWAF compliance in terms of faecal coliforms in Limpopo and Mpumalanga (overall)

\section{Microbial water quality}

For microbial profiles of final treated water (at the point of treatment and at the point of use), results revealed that $85 \%$ and $69 \%$ of water treatment plants complied with the limits set by the Department of Water Affairs (DWAF, 1996) in terms of faecal coliforms $(0 \mathrm{cfu} / 100 \mathrm{~m} \ell)$ and total coliforms $(0$ to $10 \mathrm{cfu} / 100$ $\mathrm{m} \ell$ ), respectively (Figs. 2 and 3). Microbial isolates showed that Salmonella spp. constituted the most common isolates (26.9\%), followed by Vibrio spp. (25\%) whereas Campylobacter jejuni/ coli was the least found bacteria. This underlines the possibility of the outbreak of a cholera epidemic in the region as has occurred in other parts of the country (KwaZulu-Natal Province). Regular monitoring of raw water quality is important to trace the origin of epidemics in the country.

The results of microbiological and physicochemical quality of water in these regions have demonstrated the necessity for regular monitoring of water served by the different water treatment plants to the population. The improvements of water quality at the point of use will depend on the management of

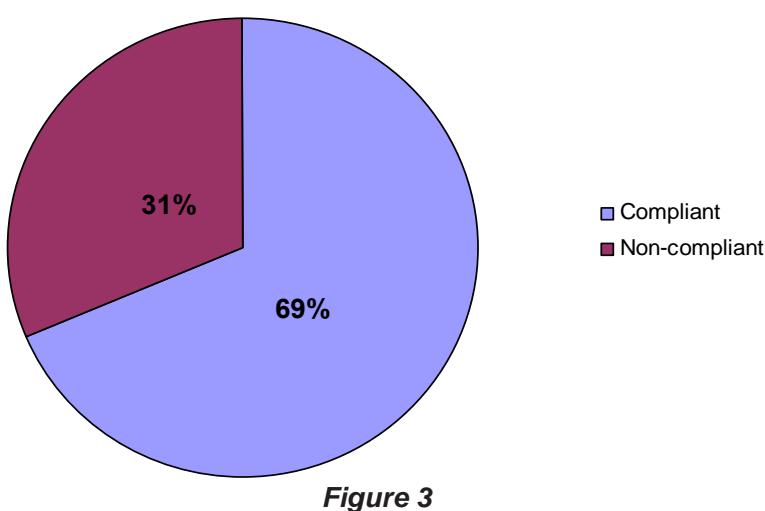

DWAF compliance in terms of total coliforms in Limpopo and Mpumalanga (overall) 


\begin{tabular}{|c|c|c|c|c|c|}
\hline \multicolumn{6}{|c|}{$\begin{array}{c}\text { TABLE } 5 \\
\begin{array}{c}\text { Microbiological properties of raw water, final water and water at point of use from small water } \\
\text { treatment plants in Mpumalanga Province }\end{array}\end{array}$} \\
\hline Indicator & Number & Minimum & Maximum & Mean & Std. deviation \\
\hline HPC of raw water & 19 & $5.2 \times 10^{3}$ & $7.5 \times 10^{6}$ & $4.4 \times 10^{4}$ & $1.7 \times 10^{4}$ \\
\hline HPC of final water & 19 & $2.4 \times 10^{2}$ & $6.2 \times 10^{3}$ & $3.4 \times 10^{2}$ & $1.9 \times 10$ \\
\hline HPC of water at point of use & 19 & $1.6 \times 10^{2}$ & $1.5 \times 10^{3}$ & $2.0 \times 10^{2}$ & $1.4 \times 10$ \\
\hline TCC of raw water & 19 & $2.8 \times 10^{4}$ & $3.3 \times 10^{4}$ & $2.0 \times 10^{4}$ & $2.8 \times 10^{3}$ \\
\hline TCC of final water & 19 & $1.0 \times 10^{3}$ & $3.8 \times 10^{4}$ & $2.1 \times 10^{2}$ & $1.7 \times 10^{2}$ \\
\hline TCC of water at point of use & 19 & $1.00 \times 10$ & $6.3 \times 10^{3}$ & $3.1 \times 10^{2}$ & $1.3 \times 10^{2}$ \\
\hline FCC of raw water & 19 & $5 \times 10^{4}$ & 360 & 88.0 & 87.2 \\
\hline FCC of final water & 19 & $1.6 \times 10^{3}$ & $4.2 \times 10^{4}$ & $3.5 \times 10^{2}$ & $1.0 \times 10^{2}$ \\
\hline FCC of water at point of use & 19 & $1.0 \times 10^{2}$ & $12 \times 10^{3}$ & $1.7 \times 10$ & $1.2 \times 10$ \\
\hline \multicolumn{6}{|c|}{$\begin{array}{l}\text { Limits for no risk } \\
\text { Heterotrophic plate count (HPC): } 0 \mathrm{cfu} 100 \mathrm{~m}^{-1} \text {; total coliform count (TCC): } 0 \mathrm{cfu} 100 \mathrm{~m} \ell^{-1} \text {; faecal coliform: } 0 \mathrm{cfu} \\
100 \ell^{-1}\end{array}$} \\
\hline
\end{tabular}

\begin{tabular}{|c|c|c|c|c|c|}
\hline \multicolumn{6}{|c|}{$\begin{array}{c}\text { TABLE } 6 \\
\text { Microbiological properties of raw water, final water and water at point of use from small water } \\
\text { treatment plants in Limpopo Province }\end{array}$} \\
\hline & $\mathbf{N}$ & Minimum & Maximum & Mean & Std. deviation \\
\hline HPC of raw water & 34 & $4.7 \times 10^{2}$ & $5.6 \times 10^{6}$ & $4.04 \times 10^{5}$ & $1.1157 \times 10^{6}$ \\
\hline HPC of final water & 34 & $1.8 \times 10^{3}$ & $3.1 \times 10^{4}$ & $1.836 \times 10^{3}$ & $5.590 \times 10^{3}$ \\
\hline HPC of water at point of use & 33 & $1.2 \times 10^{2}$ & $3.0 \times 10^{3}$ & $1.69 \times 10^{2}$ & $5.88 \times 10^{2}$ \\
\hline TCC of raw water & 34 & $1.5 \times 10^{4}$ & $7.5 \times 10^{4}$ & $5.5 \times 10^{3}$ & $1.3575 \times 10^{4}$ \\
\hline TCC of final water & 34 & $1.6 \times 10^{3}$ & $3.6 \times 10^{3}$ & $1.24 \times 10^{2}$ & $6.15 \times 10^{2}$ \\
\hline TCC of water at point of use & 33 & $1 \times 10^{2}$ & $2.5 \times 10^{3}$ & $1.2 \times 10$ & $4.5 \times 10$ \\
\hline FCC of raw water & 34 & $3.1 \times 10^{4}$ & $3.8 \times 10^{5}$ & $1.18 \times 10^{4}$ & $6.5076 \times 10^{4}$ \\
\hline FCC of final water & 34 & $2.0 \times 10^{2}$ & $3.6 \times 10^{3}$ & $3.55 \times 10$ & $1.1 \times 10$ \\
\hline FCC of water at point of use & 34 & $2 \times 10^{2}$ & $5.8 \times 10^{2}$ & $3.0 \times 10$ & $1.5 \times 10$ \\
\hline \multicolumn{6}{|c|}{$\begin{array}{l}\text { Limits for no risk } \\
\text { Heterotrophic plate count (HPC): } 0 \mathrm{cfu} 100 \mathrm{~m}^{-1} \text {; total coliform count (TCC): } 0 \mathrm{cfu} 100 \mathrm{~m} \ell^{-1} \text {; faecal coliform: } 0 \mathrm{cfu} \\
100 \ell^{-1}\end{array}$} \\
\hline
\end{tabular}

different units. More consideration needs to be given to the filtration systems and particularly to the training of plants operators. In some plants rapid gravity sand filters were used in combination with pressure filters of different volume and the water treated by both systems were mixed in the final reservoir. This made the assessments of functional units difficult and may result in poor water quality been served to the consumers

\section{Administrative issues}

Most of the plants were generally run by operators under the supervision of a superintendent. In the designated provinces, most operators (69\%) did not have enough technical knowledge of the plant. These included inability to determine flow rates, chlorine dosage or to effect minor repairs to equipment. However, the supervisors were fairly knowledgeable about the functioning of the system although most of them had little knowledge of the national and international water quality standards. In some cases the operators acted more like guards of the plants or were used for general labour and referred questions related to technical issues to the supervisors. Respondents at the various SWTPs maintained that the organogram was not often adhered to and this resulted in perceived overlap of activities. Dosing pumps were generally set by supervisors and operators were not mandated to change the dosages until the arrival of the supervisors.
Lack of proper communication between supervisors, operators and officers appeared to be a problem. The training of operators will be essential for the smooth running of the plants and most operators expressed their willingness to undergo some training. Most of the operators and supervisors interviewed did not have good knowledge of the flow rates at which their plants were being operated. Generally the chemical dosing rates were determined by experience. Very few knew their chemical dose rates or how to calculate them. In Mpumalanga, 7 (37\%) plants had the equipment to measure turbidity, $\mathrm{pH}$ and chlorine residual although these were not always used. Coagulant doses were adjusted manually usually based on the appearance of the floc and sometimes also based on the taste of the water when alum was used. Chlorine doses were also set manually and some plants were overdosing chlorine particularly in Limpopo (22\%) in the final water and (11\%) in the distribution system. In Mpumalanga chlorine was overdosed in $5(26 \%)$ of the plants in the final water.

All the plants reported that an external monitoring group (the district municipality, national microbial monitoring programme or some private company) visited the plants approximately once a month or once every three months; although most plants (74\% in Mpumalanga and $72 \%$ in Limpopo) complained about a lack of feedback from the external monitors.

Most of the plants were automated with a telemetric control panel. This generally facilitated the operator's work and limited 
some overdosing errors as well as the provision of water to central reservoirs. The maintenance record of equipment in some plants was not encouraging with dirty reservoirs in some plants. Specific administrative issues observed are presented below:

\section{Poor maintenance practices}

Lack of maintenance of equipment was noted to be a major management problem. Approximately $60 \%$ of the SWTP operators interviewed in both provinces mentioned that equipment was not regularly maintained. This led to periodic equipment failure and consequently poor water quality. Some operators asserted that the culture in most SWTPs was a culture of repairing or replacing of equipment, rather than planned maintenance of equipment. Several factors have been implicated in exacerbating the culture of poor maintenance. Such factors include lack of technical skills and appropriate training, inadequate or lack of relevant experience, inadequate funds and personnel. For example, in Mpumalanga and Limpopo, between $23 \%$ to $28 \%$ of the operators reportedly had educational qualifications of standard 8 (Grade 10 ) $51 \%$ to $56 \%$ with Grade 12 and approximately $22 \%$ were enrolled in post-matriculation studies. The implications of these trends are enormous because they typify the shortcomings and potential dangers in the water delivery system due to lack of appropriate qualifications and training The in-service training component is exemplified by the fact that, in all the SWTPs studied, in both provinces, about 44 to $47 \%$ of the operators had not undergone relevant and appropriate training to enable them to acquire technical skills for the job. International bench marks vary and no uniformity of opinion on what constitutes relevant and appropriate training exist. In addition, it is the pride taken by dedicated operators/ workers to make something work properly that very often makes the difference, not so much the level of education.

\section{Poor remuneration}

Poor service conditions were also cited as hampering water service delivery. Examples of poor conditions of employment highlighted included lack of comprehensive medical aid scheme for operators, inadequate in-service training and capacitation, lack of motivation of operators by senior management, bureaucratic processes and poor salaries. In terms of salaries, about $30 \%$ to $32 \%$ of the operators earned between R1 000.00 and R2 000.00 per month while $41 \%$ to $43 \%$ earned between R3 000.00 and R4 000.00 per month and less than $40 \%$ earned above R5 000.00 in the SWTPs studied in the designated provinces.

In addition, current schemes for upward educational mobility or in-service capacitation were either non-existent or not implemented in some of the SWTPs visited across the designated provinces. This created a situation of frustration and burnout due to a lack of relevant education, training, skills development and performance of routine duties over years and poor incentives. Performance bonuses based on meeting performance objectives and on the job training are necessary and should be introduced or promoted.

\section{Insufficient financial capacity}

Inadequate budgeting and financing were also reported to hamper service delivery in SWTPs studied in both provinces. In virtually all the SWTPs studied in the designated provinces, inadequate funding for operating and implementation activities was mentioned as a huge drawback for effective and efficient water service delivery. Although personnel interviewed were not aware of the level of funding or budgeting for SWTPs, they were unanimous in asserting that funding was grossly inadequate or mismanaged because, in most cases, operational activities were delayed or obviated due to the lack of funds.

\section{Inadequate community involvement}

Poor involvement of local communities was noted to be rampant at sub-national water service provision levels. Personnel from SWTPs mentioned that they did not interact regularly with their respective communities to ascertain current problems encountered and to offer solutions. At best, they asserted that community involvement was informal and not coordinated.

Community participation could inform technology choices, quality of service, project citing and management structures. Experience from community projects indicates that community participation and involvement are critical to quality improvement and project sustainability. Inadequate community involvement causes a lapse in relaying information on water quality, management issues that may affect water distribution or inability to avoid or manage community concerns and displeasures before they spill into protest actions or crises situations. Sensitising management practices to the above challenges is critical to the sustainability of safe and reliable water supply.

\section{Human resources}

Co-ordinated efforts should equally be put in place to maximise the human resource capacity available in the water provision support system in the provinces. Such efforts could be achieved through strategic partnerships with relevant support agencies. Such partners could include academic institutions, research bodies, community social networks, CBOs, NGOs and relevant government departments. Partnership with research and academic institutions also offers opportunities for technical assistance and manpower through internship programmes where suitably prepared students and research fellows can take part in water supply activities. Capacity building should include technical, social, financial, managerial and institutional assistance (WHILR, 2003).

In maintaining the quality of water supply, core managerial function is critical in assuring availability of adequate stocks of water treatment chemicals. For instance, an interruption in the supply of coagulants or disinfectants as was the case in some SWTPs studied either due to system failures or unavailability would constitute a major emergency. To avoid this danger, proper recording of the rate of use of the various chemicals, actual stock-taking by treatment plant operators and timely replenishment are essential. This should also be closely monitored by higher authorities. However, respondents of the various SWTPs studied noted poor recording and documentation by different levels of management as the principal causes for stock depletion or interruption of supply of chemicals, reagents and equipments. In most cases, operators lacked the training to keep inventories of chemicals, reagents and equipment which may lead to stock depletion, with ripple effects on quality of service delivery

\section{Emergency plans}

In the event of the distribution of unsafe water, appropriate emergency plans should be instituted to avert or minimise the effect of the poor water quality. Such plans would initially con- 
sist of emergency prevention measures which are mostly related to plant maintenance, strikes and sabotage, natural disasters, equipment failures, ensuring adequate supply of chemicals, and various measures to protect the water treatment and distribution systems. More than $50 \%$ of the operators were not aware of the existence of emergency prevention methods. This was generally attributed to poor communication between operators and management or operators and consumers.

The plan should equally have a detailed description of the role and responsibilities of the different participants in water service provisions (from the district water service administrator to plant operators/shift workers and community members). Efficient communication protocols should also be built into the emergency and routine plans. Such communication protocols should include internal communication and public communication procedures.

In conclusion, periodic monitoring of water quality, adherence to a maintenance culture, increased budgetary allocations and in-service training, in addition to other incentives would enhance the profile and quality of service delivery of SWTPs in South Africa.

\section{Acknowledgments}

The authors are very grateful to the Water Research Commission (WRC) and National Research Foundation (NRF) for providing the funds for this project. We would also like to thank the administrators in various municipalities and offices of DWAF and Biowaters, the supervisors, superintendents and operators of the various plants visited.

\section{References}

ANON (1994) The Microbiology of water. Part 1-Drinking Water. Report on Public Health and Medical Subjects No. 71. Methods for the Examination of Waters and Associated Materials. London; HMSO, 1994.

ASHBOLT NJ (2004) Microbial contamination of drinking water and disease outcomes in developing regions. Toxicol. 198 (1-3) 229-238.

CASLAKE LF, CONNOLLY DJ, MENON V, DUNCANSON CM, ROJAS R and TAVAKOLO J (2004) Disinfection of contaminated water by solar irradiation. Am. Soc. Microbiol. 70 (2) 1145-1150.
DWAF (1996) South African Water Quality Guidelines (Vol. 1) Domestic Uses (2nd edn.) Department of Water Affairs \& Forestry, Pretoria.

DWAF (1998) Quality of Domestic Water Supplies. Assessment Guide. 1 ( $2^{\text {nd }}$ edn.) Department of Water Affairs \& Forestry, Department of Health and Water Research Commission.

EDBERG SC, RICE EW, KARLIN RJ and ALLEN MJ (2000) Escherichia coli: the best biological drinking water indicator for public health protection. J. Appl. Microb. Symp. Suppl. 88 106S-116S.

MINISTRY OF HEALTH (MOH) (2003) New Approaches to Handling Protozoa Criteria. Wellington: New Zealand Ministry of Health.

MOMBA M.NB, NDATISO Sand BINDS MA (2003) Effect of a combined chlorine-monochloramine process on the inhibition of biofilm regrowth in potable water systems. Water Supply 3 (1-2) 215-221.

MOMBA MNB, CLOETE TE, VENTER SN and KFIR R (2000) Influence of disinfection processes on the microbial quality of potable groundwater in a laboratory-scale system model. J. Water SRT Aqua 49 23-33.

MUYIMA NYO and NGCAKANI F (1998) Indicator bacteria and regrowth potential of the drinking water in Alice, Eastern Cape. Water SA 24 (1) 29-34.

NATIONAL INSTITUTE OF COMMUNICABLE DISEASES (NICD) (2005) Typhoid fever outbreak in Delmas. Communicable Disease Communiqué September 2005.

NISSINEN TK, IT MIETTINEN PJ, MARTIKAINEN B and VARTIAINEN T (2002) Disinfection by-products in Finnish drinking waters. Chemosphere 48 9-20.

OBI CL, PO BESSONG, MNB MOMBA, N POTGIETER, A SARNIE and EO IGUMBOR (2004) Profiles of antibiotic susceptibilities of bacterial isolates and physico-chemical quality of water supply in rural Venda communities, South Africa. Water SA 30 (4) 515-520.

OBI CL, POTGIETER N, BESSONG PO and MATSAUNG G (2002) Assessment of the microbial quality of river water sources in rural Venda communities in South Africa. Water SA 28 (3) 287-291.

WHO (2000) Global Water Supply and Sanitation Assembly 2000 Report. Available at http://www.who.int/water sanitation health/ Globalassembly/GlobalTOC.htm . Accessed in August 2002.

WHO (2001) Guidelines for Drinking-Water Quality (2 ${ }^{\text {nd }}$ edn.) Microbiological Methods. Vol. 1. World Health Organization, Geneva.

WHO (2003) Emerging Issues in Water and Infectious Disease. World Health Organization, Geneva.

ZHANG X, MINEARA RA, GUOB Y, HWANGB CJ, BARRETT SE, IKEDAC K, SHIMIZU K and MATSUI S (2004) An electrospray ionization-tandem mass spectrometry method for identifying chlorinated drinking water disinfection byproducts. Water Res. 383910 3920. 
Available on website http://www.wrc.org.za ISSN 0378-4738 = Water SA Vol. 33 No. 2 April 2007 ISSN 1816-7950 = Water SA (on-line) 